\title{
KONSEP ILMU PENGETAHUAN SYED HUSSEIN NASHR: SUATU TELAAH RELASI SAINS DAN AGAMA
}

\section{Syarif Hidayatullah}

Fakultas Filsafat, Universitas Gadjah Mada, Yogyakarta

\section{Email: syarifhidayatullah@ugm.ac.id}

\section{Abstrak}

Syed Hussein Nashr adalah salah satu intelektual terkemuka dalam diskursus relasi sains dan agama, khususnya di dunia Islam. Meneliti pemikiran Nashr adalah sebuah upaya yang relevan dan signifikan untuk lebih memahami salah satu aspek penting dalam perkembangan keilmuan di dunia Islam secara khusus, dan keilmuan pada umumnya di Barat. Rumusan masalah penelitian terdiri, yaitu: pertama, Bagaimana konsep Syed Hussein Nashr tentang ilmu pengetahuan?dan, kedua, Bagaimana relevansi konsep pengetahuan Syed Hussein Nashr dalam pengembangan wacana sains dan agama? Objek material penelitian terfokus pada konsep Nashr tentang ilmu pengetahuan dan merumuskan relevansinya pengembangan wacana sains dan agama. Sedangkan objek formal dalam penelitian digunakan filsafat ilmu, dengan pendekatan metodologis secara deskpritif-analitis. Hasil penelitian mengungkapkan: pertama, konsep Nashr tentang ilmu pengetahuan bertumpu pada prinsip unitas; yaitu paham kesatupaduan dan interelasi dari segala yang ada, sehingga memungkinkan terjadinya integrasi pengetahuan dan tindakan manusia secara harmonis. Nashr menawarkan konsep Scientia sacra agar nilai kesucian dari Islam dapat menjiwai ilmu pengetahuan yang berasal dari di Barat. Kedua, Nashr adalah penulis pertama buku sejarah ilmu pengetahuan pada zaman Islam yang cukup komprehensif. Pengaruh Nashr didukung oleh posisi pemikiran Nashr terkait ilmu pengetahuan itu sendiri dan dengan perkembangan narasi besar, yaitu Islamisasi ilmu atau sains Islam, yang tengah bergulir di kalangan intelektual Muslim. 
Kata Kunci: Pengetahuan, Tauhid, Kesucian, Scientia sacra

\section{Abstract}

Syed Hussein Nashr is one of the leading scholars in the field of science and religion relations, especially in Islamic world. A study on Nashr's thought in this field is an important and necessary effort to understand one of the aspects that contribute particualrly to the development of sciences in the Islamic world, and in the Western world generally. The article aims to understand (1) Syed Hussein Nashr's concept on science? And (2) the relevance of Nashr's concept on science to the development of discourses in science and religion? This study focuses on Nashr'sconcept on science and its relevance to the development of the science and religion discourse. This study deploys a framework of philosophy of science, while applying descriptive and analitycal methodological approach. This study finds that: first, Nashr's concept on science bases it self on the principle of unity, that is a concept of one-ness and inter-relationship of all beings, which allows integration of knowledge and action of human being into harmony. Nashr offers idea of sacred knowledge (scientia sacra) to allow the sacred values embeded in Islamic teaching to spiritualize modern sciences which are developed in the Western world. Secondly, Nashr was the first Muslim scholar who wrote a comprehensive work about history of science in Islam. His influence is attributed to his contribution to the dicsussion of science and to a grand narrative, namely, Islamization of knowledge or Islamic science, that had become a major scholarly debate among Muslim scholars.

Keywords: Knowledge, Unity, Sacred, Scientia sacra

\section{PENDAHULUAN}

Dalam konteks sejarah modern Islam, sesungguhnya wacana relasi sains dan agama dapat dilacak jauh sebelum Ian Graeme Barbour mensistemisasi temuannya dan kemudian berpidato di depan forum Gifford Lectures; sebuah forum akademik prestisius yang bertujuan mempromosikan studi tentang theology of nature dalam 
pengertian luas sejak 1989 hingga 1991. Dalam riset Syamsuddin, misalnya, wacana relasi sains dan agama dapat ditelusuri sejak upaya Turki mengadopsi sains Barat pasca kekalahan mereka oleh kolonialisasi Barat, yang sebagian faktor penyebabnya adalah ketertinggalan teknologi militer dan ilmu pengetahuan. Upaya Turki tersebut disusul oleh Muhammad Alidi Mesir pasca pengusiran tentara Napoleon (1778 M), meskipun seperti halnya Turki, masih terfokus pada pembangunan kembali peradaban Islam dalam konteks merespon modernitas Barat (2012: 20). Namun demikian, menurut Zainal Abidin Bagir, pemilihan Ian Barbour sebagai tokoh yang dianggap membangun bidang studi interdisipliner sains dan agama adalah hal yang sangat tepat. Sebab, sejak setengah abad sebelum festshrift bertajuk Fifty Years in Science and Religion-Ian G. Barbour and His Legacy terbit pada 2004, Barbour telah menulis puluhan buku dan artikel mengenai bidang kajian ini, mendefinisikan metodologinya, dan membuat tipologi yang amat populer, terutama melalui buku terakhirnya, When Science Meets Religion, pada tahun 2000, sebuah buku kecil yang merupakan kulminasi penjelajahannya, yang mengundang ketertarikan khalayak intelektual sehingga banyak diterjemahkan ke dalam sedikitnya 9 bahasa, termasuk bahasa Indonesia. Festschrift tersebut digagas oleh para penggiat kajian sains dan agama sebagai persembahan atas kontribusi Barbour, yang melalui karya pionirnya pada 1950-1960-an membantu terbentuknya disiplin ilmu baru, sains dan agama, serta karya-karya selanjutnya selama kurun waktu lima dasawarsa telah menggali seluruh aspeknya secara mendalam (2008: 49).

Upaya lebih spesifik dalam relasi sains dan agama di dunia Islam, menurut Bagir (2002: 144; lihat juga Hidayatullah, 2017: 67 ), terjadi pada dasawarsa 1970-an hingga sekitar awal 1990-an di mana berkembang sebuah dinamika baru di dunia Islam, khususnya dalam persoalan relasi antara Islam dan ilmu pengetahuan, dengan munculnya Islamic science (ilmu pengetahuan Islam) atau Islamisasi ilmu (Islamization of knowledge). Memang tidak cukup mudah untuk memastikan siapa tokoh intelektual Muslim yang dianggap sebagai perintis awal yang memperkenalkan istilah tersebut. Namun 
demikian,yang bisa dipastikan adalah banyaknya bermunculan sejumlah nama atau kelompok intelektual Muslim yang berusaha memaknai istilah tersebut dengan cara yang beragam, bahkan tidak jarang saling bersilang pendapat. Menurut Zaenal Abidin, secara realitas, memang terdapat silang pendapat tentang siapakah tokoh yang pertama kali menggagas trend Islamisasi Ilmu ini, namun ia mengajukan pendapat Wan Mohd Nor Wan Daud, intelektual Malaysia yang murid sekaligus teman Fazlur Rahman, bahwa gagasan tersebut pertamakali dicetuskan oleh Syed Muhammad alAttas, yang kemudian diteruskan dan dikembangkan oleh Ismail Razi al-Faruqi dan sejumlah sarjana Muslim lainnya (2008: 7).

Pada perkembangan lebih lanjut dari wacana relasi sains dan agama (baca: Islam) bermunculan pandangan yang beragam dari kalangan intelektual Muslim, yang meruncing pada persoalan sains yang khas Islam yang berbeda dengan sains Barat. Perbedaan yang mengemuka adalah di seputar menentukan wilayah keberadaan sains Islam yang berbeda dengan sains Barat, khususnya pada ilmu-ilmu kealaman. Terdapat beberapa kecenderungan yang bisa dipetakan secara jelas, yaitu: kelompok pertama, saintis berhaluan fundamentalis, yang menolak sains Barat sepenuhnya dan berobsesi membangun sains Islam secara khas dengan objek dan metode yang samasekali berbeda dengan objek dan metode sains Barat. Kelompok ini mendapat penentangan keras oleh sebagian kalangan yang memiliki pandangan bahwa sains itu netral, bebas nilai, dan universal. Kelompok kedua, para pemikir yang setuju dengan gagasan sains Islam, namun tidak sepenuhnya seragam tentang bagaimana konsep sains Islam itu dibangun. Ada yang mengusulkan sains Islam melalui penyesuaian dengan al-Quran atas temuan-temuan sains, yang kemudian disebut sebagai Bucailis, sebab dilakukan dan diinisiasi oleh Murice Bucaile, sehingga namanya dinisbatkan sebagai representasi kecenderungan ini, seorang dokter ahli embriologi berkebangsaan Perancis, dan Harun Yahya, saintis Muslim Turki. Kelompok ketiga, para pemikir yang tidak sepenuhnya menolak Barat dengan tetap mengakui bagian-bagian yang sejalan sains Islam. Mereka dikenal sebagai penganut Science in Islamic Perspective. Menurut Syamsuddin, keragaman pandangan tersebut 
membutuhkan kajian-kajian lebih lanjut dan mendalam pada akar persoalan dan prinsip-prinsip konseptual serta konteks kontroversinya (2012: 22).

Perkembangan baru ini tidak terlepas dari munculnya kesadaran historis di kalangan intelektual Muslim terhadap kontribusi Islam bagi kemajuan ilmu pengetahuan Barat, kendati pun seringkali tidak diakui ilmuwan Barat. Cemil Akdogan, sebagaimana dikutip Abidin, dalam tulisannya Islamica, tahun ke-I, no. 4, Januari-Maret 2005, berusaha menelusuri jejak kontribusi Islam dalam asal-usul sains modern di mana ia menyimpulkan bahwa dalam perspektif sejarah sains modern, asal-usul ilmiah atau revolusi ilmiah yang terjadi Barat sesungguhnya berasal dari peradaban Islam. Akdogan mengandaikan beberapa peristiwa sejarah yang jika saja tidak terjadi dan dialami umat Islam, yaitu: pertama, tidak saling berperang diantara mereka; kedua, tidak ada penyerangan terhadap Muslim di Andalusia (Spanyol); dan ketiga, tidak ada serangan Mongol dan perusakan serta pemusnahan sentra-sentra intelektual yang vital di pusat-pusat peradaban Islam pada abad ke-13, maka akan terlahirlah dari rahim Islam figur-figur intelektual sekaliber Descartes, Gassendi, Hume, Copernicus, karena justru benih-benih filsafat mekanika, emperisme, elemen-elemen utama dalam heliosentrisme, dan instrumen-instrumen Tycho Brahe, dapat ditemukan dan disemai dari karya-karya al-Ghazali, Ibnu Shathir, para astronom di observatorium Maragha, dan karya-karya Taqiyyuddin (2008: 32).

Dengan demikian, meneliti pemikiran salah satu intelektual terkemuka dalam pusaran relasi sains dan agama seperti Syed Hussein Nashr adalah sebuah upaya yang relevan dan signifikan untuk lebih memahami salah satu aspek penting dalam perkembangan keilmuan di dunia Islam secara khusus, dan dinamika keilmuan pada umumnya. Dengan latar belakang seperti dikemukakan di atas, maka rumusan masalah yang akan diteliti lebih jauh dalam penelitian ini adalah: pertama, bagaimana konsep Syed Hussein Nashr tentang pengetahuan?, dan, kedua, bagaimana relevansi konsep pengetahuan Nashr dalam pengembangan wacanasains dan agama?. Dengan demikian, penelitian ini bertujuan 
untuk mengetahui dan memahami: pertama, konsep Syed Hussein Nashr tentang pengetahuan, dan, kedua, merumuskan relevansi konsep pengetahuan Nashr bagi pengembangan wacana sains dan agama.

\section{DINAMIKA KEILMUAN DALAM RELASI SAINS DAN AGAMA}

Ilmu (sains) dan agama, menurut Cuk Ananata Wijaya (2006: 175) merupakan prestasi manusiawi, yang pada hakikatnya, muncul dari semangat yang sama-agar manusia dapat survive. Dengan kata lain, ilmu dan agama lahir karena kebutuhan, yaitu untuk menjawab berbagai macam tantangan yang selalu dihadapi manusia dalam eksistensinya. Ilmu dan agama merupakan cara yang dimiliki manusia untuk mengenali misteri kebenaran dan kenyataan di dalam struktur pengetahuan yang lebih luas. Jadi, secara epistemologis, ilmu dan agama merupakan jenis pengetahuan yang dimiliki manusia di antara jenis pengetahuan yang lain: common sense, mitos, ideologi, dan seni. Satu sisi, nilai kebenaran agama menjadi absolut dan mutlak serta abadi karena bersumber dari sesuatu yang absolut dan abadi pula, yakni Tuhan (Hidayatullah, 2006: 135). Di sisi lain, ilmu memiliki nilai kebenaran yang bersifat relatif, karena sangat bergantung pada bagaimana penalaran dan pengalaman manusia dalam proses pencarian hakikat kebenaran. Oleh sebab itu, menurut Kuswanjono, ilmu kerap dikatakan bersifat antroposentris; yang menempatkan kebenaran pada penalaran dan pengalaman manusia (2016: 303). Namun demikian, menurut Wijaya, dengan mengutip Peter Antony Bertocci, ilmu dan agama sesungguhnya hanya berbeda perspektif di dalam melihat realitas yang sama. Menurutnya, Seseorang dapat menjadi ilmuwan yang handal sekaligus sebagai penganut agama yang taat dengan tanpa mengalami gangguan secara fisik maupun mental. Sejauh ini belum pernah ditemukan kasus psikosomatik karena orang menguasai bidang ilmu tertentu dan taat beribadah. Bahkan ada kecenderungan bahwa semakin luas dan mendalam penguasaan seseorang atas ilmu tertentu justru dirinya merasa semakin kecil dan tidak bermakna apa-apa, sehingga semakin kuat kesadarannya bahwa ada sesuatu Yang Maha Besar yang menguasai tertib alam semesta, yang segala perintah-Nya wajib 
dipatuhi. Walau pun tidak juga tertutup kemungkinan bahwa seseorang, terutama di dunia Barat, semakin baik penguasaannya atas ilmu membuat dirinya menjadi ateis dan tidak percaya akan adanya Tuhan (2006: 182).

Ilmu (sains) dan agama, menurut Arqom Kuswanjono, pada awalnya tidak mengalami persoalan sebelum Copernicus (1473-1543) dan Galileo Galilei (1564-1642) mengemukakan temuan ilmiahnya tentang pusat alam semesta, yaitu bahwa pusat alam semesta adalah matahari (teori heliosentrisme),bukan bumi (teori geosentrisme); sebagaimana diyakini oleh gereja selama berabad-abad. Sejak saat itu, relasi sains dan agama selalu menarik untuk dibicarakan sebab kerapkali melahirkan persoalan yang tak pernah selesai dan usang, baik pada ranah ontologis, epistemologis, maupun aksiologis (2010: 1). Problem keilmuan di Barat, khususnya persoalan relasi sains dan agama, terus berlanjut dan mendapatkan momentum kedua, pasca perseteruan gereja versus Copernicus dan Galilei yang didukung saintis, ketika pada 1870 secara mengejutkan Max Muller mengemukakan satu istilah baru, science of religion (ilmu agama), pada audiens sebuah kuliah umum, meskipun forum tersebut bukan kesempatan pertama Muller dalam memperkenalkan istilah tersebut. Menurut Mircea Eliade, Muller pertama kali menyebut nama Religionswissenchaft (Ilmu Agama-Agama, science of religions ) atau "Ilmu Perbandingan Agama" pada 1867 dalam pengantar buku Chips from a German Workshop (2000: 61; lihat juga Hidayatullah, 2011: 14). Sebab usaha yang dilakukannya, menurut Syarif Hidayatullah, Max Muller (1923-1900) akhirnya ditahbiskan sebagai tokoh perintis yang membangun disiplin ilmu studi agama secara sistematis (2011: 20).

Apa yang dirintis oleh Muller tersebut merupakan hal yang dianggap aneh dan ganjil sebab pasca kemunculan teori evolusi yang digagas Charles Darwin melalui karya monumentalnya, buku Orign of Species, menurut Kuswanjono, kebenaran sains dan agama semakin tidak mudah untuk dipersandingkan dan, apalagi, dipertemukan, Di satu pihak, ilmu meyakini bahwa alam semesta, termasuk manusia di dalamnya, terjadi karena proses alamiah yang panjang dan bertahap (teori evolusionisme), sementara agama, di pihak lain, 
memercayai bahwa alam semesta diciptakan langsung oleh Tuhan, seperti yang dianut oleh teori kreasionisme (2010: 2). Dalam kenyataannya memang terkadang konsep ilmu bertentangan dengan konsep agama, termasuk tentang penciptaan manusia tersebut. Ilmu dengan buktinya yang meyakinkan menyatakan bahwa manusia, seperti makhluk hidup yang lain, merupakan hasil evolusi yang panjang. Namun agama mengajarkan (khususnya agama Semitik: Yahudi, Kristen, dan Islam) bahwa manusia pertama adalah Adam dan Hawa, yang dicipta Tuhan dari tanah (Wijaya, 2006: 182). Tuhan yang harus diterjemahkan oleh manusia. Jika hal tersebut dipahami secara harafiah memang persoalan untuk sementara dapat dikatakan selesai. Jika agama menutup penafsiran secara terbuka, selamanya ilmu dan agama akan memiliki konsep yang terus bertentangan tentang penciptaan. Semakin maju intelektualitas manusia ada kecenderungan bahwa dirinya tidak puas melihat sesuatu hanya secara harafiah. Orang seperti ini akan berpikir: di balik teks ada konteks, di balik kata ada makna, yang implisit perlu dieksplisitkan, simbol harus diterjemahkan, pemahaman harus disesuaikan dengan zaman (Wijaya, 2006: 183).

Pada konteks kekinian, isu sains dan agama kembali marak, namun dengan kecenderungan baru yang lebih positif dibanding kecenderungan awal di atas, yang berkesan negatif dan beraroma konflik. Menurut Achmad Maimun Syamsuddin, fenomena baru tersebut bisa dikonfirmasi dengan banyaknya seminar, konferensi, artikel jurnal, dan buku-buku bertema ilmu dan agama. Syamsuddin mencontohkan, the Center for Theology and the Natural Science, yang menghelat sebuah seminar bertopik "Science and The Spiritual Quest" pada 1998, yang kemudian memicu Newsweek untuk menurunkan rubrik bertajuk "Science Finds Gods", sebuah tema yang tak lazim bagi media cetak berkaliber internasional ini. Demikian pula Jurnal Zygon, adalah contoh lain yang menandai kesemarakan wacana sains dan agama. Perbincangan relasi sains dan agama semakin menggema di kalangan ilmuwan dan agamawan hingga akhirnya mendapatkan juru bicara yang sangat fasih melalui sosok Ian G. Barbour (2012: 19). Sejak menerbitkan buku pertama bertema sains dan agama, Issues in Science and Religion, pada 1961, 
Barbour seakan menjadi amunisi utama sekaligus momentum ketiga bagi dinamika wacana ilmu dan agama tersebut. Reputasi Barbour begitu cepat melesat dengan mendapatkan pengakuan masyarakat internasional melalui undangan sebagai dosen tamu pada serangkaian kuliah di forum Gifford Lectures. Sejumlah nama terkemuka lainnya yang pernah mendapatkan kesempatan yang sama untuk memberikan kuliah di forum ini adalah Annemarie Schimmel, Nels Bohr, Paul Ricoeur, dan William James, di Universitas Edinburgh pada 1981 (2012: 12).

Menurut Zaenal Abidin Bagir (2006: 3), diskursus tentang sains dan agama menemukan bentuk baru yang subur dan sistemik dalam sekitar empat dasawarsa terakhir. Maksud sistemik di sini adalah bahwa, seperti halnya suatu bidang kajian, ia sudah terdapat perdebatan tentang pendekatan, metodologi dan ruang lingkupnya, tumbuhnya forum-forum akademis yang mewadahi perdebatan tersebut baik dalam bentuk seminar, konferensi, maupun penerbitan jurnal yang khas, dan bahkan di beberapa perguruan tinggi mulai dirancang dan diimplementasikan dalam bentuk matakuliahmatakuliah terkait subjek ini, serta semakin beredarnya buku-buku teks dan referensi yang mengkaji persoalan seputar agama dan sains. Dalam konteks seperti inilah Nashr, tokoh yang pemikirannya menjadi objek penelitian ini, telah melakukan kontribusi nyata dengan menulis sejumlah buku yang berkaitan dengan wacana agama dan sains, seperti: Knowledge and Sacred (1989),Religion and The Order of Nature (1996), Islamic Art and Spirituality (1987), dan Islam and The Plight of Modern Man (1975).

\section{SEKILAS TENTANG SYED HUSSEIN NASHR}

Syed Hussein Nashr, menurut Abdurrahman Wahid dan Hashim Wahid, adalah sedikit di antara pakar kajian Islam yang mampu menembus hambatan-hambatan ilmiah dan non-ilmiah dalam mengkaji Islam sebagai objek pengkajian dengan cara yang sangat jujur dan objektif. Reputasi internasional tokoh yang pernah menjadi guru besar di universitas berbeda di tiga benua selama dua daswarsa, selama tahun 1960-an hingga 1970-an, adalah dikenal 
sebagai pemikir Muslim yang memiliki ketajaman, penglihatan, kedalaman pemikiran, kejujuran ilmiah, dan sangat independen (1983: viii-ix). Nashr yang dilahirkan pada 17 April 1933 di kota Teheran, Iran, merupakan tokoh pemikir Muslim Syiah yang sangat menonjol dan unik di dunia Islam. Keunikan pribadi dan pemikiran Nashr karena ia lahir dari tradisi Sufi-Syi'ah dan sekaligus bertumbuh dalam tradisi pemikiran Barat modern. Nashr adalah seorang tradisionalis yang ingin menggeser peradaban intelektual modern dengan matrik intelektual tradisional (Ulumuddin, 2016: 1).

Setelah melalui pendidikan awal di Iran, Nashr kemudian melanjutkan ke Massacheusetts Institute of Technology (MIT). Di institusi pendidikan ini Nashr memperoleh pendidikan tentang ilmuilmu fisika dan matematika teoritis di bawah bimbingan Bertrand Russel yang dikenal sebagai seorang filosof modern. Nashr banyak memperoleh pengetahuan tentang filsafat modern. Selain bertemu dengan Bertrand Russel, Nashr bertemu dengan seorang ahli metafisika Geogio De Santillana. Dari kedua ilmuwan tersebut Nashr banyak mendapat informasi dan pengetahuan tentang filsafat Timur, khususnya yang berhubungan dengan metafisika. Dia diperkenalkan dengan tradisi keberagamaan di Timur, misalnya tentang Hinduisme. Nashr juga berinteraksi dengan pemikiran-pemikiran para peneliti kajian ketimuran (oksidentalisme), seperti Frithjof Schuon tentang perenialisme, selain pemikiran Rene Guenon, A. K. Coomaraswamy, Titus Burchardt, Luis Massignon dan Martin Lings. Pada tahun 1956 Nashr berhasil meraih gelar Master di MIT dalam bidang geologi yang fokus pada geofisika. Setelah memperoleh derajat master, Nashr melanjutkan studi doktoral di Universitas Harvard pada 1958 dengan spesialisasi dalam kosmologi Islam dan sains. Dalam menyusun disertasi, Nashr dibimbing oleh George Sarton, namun sebelum disertasi selesai ditulis, Sarton meninggal dunia, sehingga ia mendapatkan bimbingan berikutnya dari tiga orang professor, yaitu Bernard Cohen, Hammilton Gibb dan Harry Wolfson. Disertasi Nashr berjudul "Conceptions of Nature in Islamic Thought" kemudian dipublikasikan oleh Harvard University Press pada 1964 dengan judul "An Introduction to Islamic Cosmological Doctrines". Pada H.A.R. Gibb, Nashr belajar sejarah dan pemikiran Islam, 
sedangkan tentang sejarah ilmu pengetahuan ia pelajari dari George Sarton dan sejarah teologi dan pada Harry Wolfson ia menimba ilmu filsafat (Ulumuddin, 2016: 1; Zainal, 2017: 1-7; Solichun, 2011: 3-4).

Di satu sisi Nashr sangat kredibel dalam mengapresiasi khazanah keilmuan tradisional Islam seperti karya Suhrawardi, Ibn Arabi dan Mulla Sadra. Di sisi lain, latar belakang pendidikan Barat yang ditempuhnya menjadikan ia mampu mengapresiasi khazanah intelektual Barat. Kombinasi latar belakang kultural dan intelektual tersebut membuat Nashr menempati posisi khusus dalam berbicara dan berkarya, mempunyai otoritas dalam berbicara mengenai banyak topik, terutama mengenai perjumpaan Timur dan Barat, tradisi dan modernisasi. Ditambah lagi pergaulannya yang luas, baik dengan muslim maupun non-muslim, menjadikan Nasr sebagai figur yang langka dan jarang ada bandingannya. Salah satu bentuk penghormatan kalangan internasional adalah ketika ia dipercaya menjadi dosen tamu dalam Gifford Lecture tersebut (Ulumuddin, 2016: 1; Syamsuddin, 2012: 12). Selain itu, Nashr diberi kehormatan memberikan kuliah sepanjang tahun 1994 pada forum The Edward Cadbury Lecturer di Universitas Birmingham, yang bahan perkuliahan yang ia sampaikan kemudian diterbitkan menjadi buku Religion and The Order of Nature oleh Oxford University Press pada 1996. Buku tersebut diakui oleh Nashr sebagai lanjutan dari buku Man and Nature, yang merupakan kumpulan ceramah yang ia berikan pada forum ilmiah yang tak kalah prestisiusnya yaitu Rockefeller Lecuterer di Universitas Chicago pada 1966. Selain sebagai seri kajian lanjut dari buku monumentalnya, Knowledge and the Sacred, yang terbit pada 1981 dari bahan ceramahnya di Gifford Lecture di atas, yang topik buku ini ia tuntaskan dalam buku berjudul The Need for a Sacred Science yang diterbitkan belakangan oleh Taylor \& Francis pada 2005 (Nashr, 1996: 7).

Selama berkiprah di dunia akademis dan intelektual, Nashr banyak mempengaruhi filsafat Islam modern di Iran melalui karyakaryanya. Sepanjang karir intelektualnya, Nashr telah menulis sejumlah buku dan artikel mengenai hubungan antara agama dan ilmu pengetahuan, seperti buku yang mengkaji tentang sains dan 
peradaban di dalam Islam, pertama kali diterbitkan pada tahun 1968, yang edisi Indonesia dipublikasikan penerbit Pustaka Bandung dengan judul Sains dan Peradaban dalam Islam pada 1986. Dalam karya ini, Nashr membahas arti ilmu pengetahuan dalam konteks pandangan dunia Islam dan menganalisis prestasi ilmiah tradisi Islam dalam bidang seperti kedokteran, astronomi, matematika, aljabar, kimia, fisika, geografi, dan sejarah alam. Melalui karyakaryanya, Nashr menjelma menjadi seorang intelektual Islam dan guru besar yang cukup berpengaruh di kalangan mahasiswa Islam. Di berbagai universitas terkenal di Barat, gagasan-gagasan Nashr dianggap punya prospek baru tentang fenomena lintasan intelektual dalam peradaban modern baik di Timur maupun di Barat (Ulumuddin, 2016: 2).

\section{KONSEP ILMU PENGETAHUAN SYED HUSSEIN NASHR}

Syed Hussein Nashr adalah di antara pemikir sains Islam yang mengkritik tajam paradigma sains Barat modern melalui beberapa karya ilmiah dan ceramah, seperti buku the Encounter of Man and Nature (1968), buku Man and Nature: The Spiritual Crisis of Modern Man (1968), buku Islam and the Plight of Modern Man (1975), dan buku Religion and the Order of Nature (1996). Sebagaimana yang dilakukan Ziauddin Sardar, Syed Naquib al-Attas, dan Mehdi Gholsani, kritik Nashr secara umum mengarah pada pandangan dunia sekular, materialistik dan mekanisitik. Nashr mengritik sains Barat dengan merujuk pada dampak negatifnya, terutama dianggap sebagai pemicu krisis spiritualitas, kemanusiaan, dan krisis lingkungan serta apa yang disebutnya sebagai "keterkungkungan", "kesempitan" dan "keterbatasan" sains Barat (Syamsuddin, 2012: 175-6). Kritik terhadap paradigma sekuleristik sains Barat sebenarnya muncul juga di kalangan pemikir Barat. Salah satu tokoh yang sangat fasih dalam mengargumentasikan kritik tersebut adalah Frithjof Capra terutama dalam buku, The Turning Point: Science, Societey and the Rising Culture (Syamsuddin, 2012: 221 dan 231). Sebagian orang Barat menyadari bahwa ada penyakit dalam peradaban modern. Mereka melihat bahwa peradabannya telah menghanguskan fithrah manusia, menghadang ketentraman jiwa, dan meruntuhkan nilai-nilai 
kemanusiaan. Manusia tentu saja tidak bisa mengangkat dirinya secara spiritual dengan begitu saja. Ia harus dibangunkan dari mimpi buruknya oleh seseorang yang telah sadar. Karena itu manusia memerlukan petunjuk Tuhan dan harus mengikuti petunjuk itu, agar dia dapat menggunakan seluruh potensi yang dimiliki dan agar ia mampu mengatasi rintangan dalam menggunakan akalnya (Hanaf, 2011: 4; Yakub, 2013: 4).

Pandangan Nashr mengenai pengetahuan bisa kita lihat dari konsepnya mengenai tradisionalisme Islam, namun bukan tradisionalisme Islam yang dikenal orang sebelumnya. Sebab, bagi Nashr, selama ini gerakan-gerakan fundamentalis atau revivalis Islam tak lebih merupakan dikotomi tradisionalisme-modernisme, keberadaannya justru menjadi terlalu radikal dan terlalu mengarah kepada misi politis dari pada nilai-nilai keagamaan. Sekalipun gerakan-gerakan seperti itu, atas nama pembaharuan-pembaharuan tradisional Islam. Pemahaman masyarakat yang kurang mengenai tradisionalisme Islam ataupun fundamentalisme Islam menyebabkan kedua hal ini dianggap sama. Padahal perbedaan keduanya bukan hanya dari kandungannya saja tetapi juga dari kegiatan yang dilakukan. Gerakan tradisonalisme Islam yang ditawarkan oleh Nashr, merupakan gerakan untuk mengajak kembali ke 'akar tradisi'; yang merupakan "Kebenaran dan Sumber asal segala sesuatu", dengan mencoba menghubungkan antara sekuleritas Barat dengan dimensi ke-Ilahiah-an yang bersumber pada wahyu agama. Tawaran Nashr ini dimaksud agar nilai kesucian dari Islam dapat menjiwai pengetahuan yang berasal dari di Barat lebih berkembang daripada dunia Islam kontemporer, sehingga tidak perlu disingkirkan sama sekali. Tradisionalisme Islam, ditegaskan Nashr, sesungguhnya adalah gambaran awal sebuah konsepsi pemikiran dalam sebuah bentuk Sophia Perenneis (keabadian). Tradisonalisme Islam boleh dikatakan juga disebut sebagai gerakan intelektual secara unversal untuk mampu merespons arus pemikiran Barat modern yang merupakan efek dari filsafat modern yang cenderung bersifat profanik, dan selanjutnya untuk sekaligus dapat membedakan gerakan tradisionalisme Islam tersebut dengan gerakan 
fundamentalisme Islam, seperti halnya yang dilakukan di Iran, Turki dan kelompok fundamentalis lain. Usaha Nashr untuk menggulirkan ide semacam itu paling tidak merupakan tawaran alternatif sebuah nilai-nilai hidup bagi manusia modern maupun sebuah negara yang telah terjangkit pola pikir modern, dengan sifat profanik dan sekuleristik, untuk kemudian kembali pada sebuah akar tradisi yang bersifat transedental dengan menjadikan ajaran Islam sebagai pondasi dasar bagi pengembangan ilmu pengetahuan (Kurniawan, 2010: 1-2).

Menurut John Hendrik Meuleman, Islamolog Belanda, Nashr adalah pemikir Islam yang memiliki sikap positif terhadap pemikiran Islam dalam bentuknya yang tradisional, termasuk aspek tertentu dari 'irfan, yang oleh sementara pemikir Islam lain, misalnya Abid alJabiri, kurang begitu dihargai. Sikap tersebut dibaca oleh Meuleman disebabkan Nashr bergaul begitu intensif dengan pemikiran Barat sejak ia menetap di Amerika pasca Revolusi Iran. Salah satu tujuan utama dari keseluruhan pemikiran Nashr adalah ingin menegaskan dan menjelaskan keunggulan tradisi Islam atas pemikiran Barat modern yang dinilai telah meninggalkan dan melepaskan diri dari yang suci atau yang Ilahi serta tidak bisa memahami sakralitas Ilahi tersebut. Dampak yang dinilai buruk oleh Nashr dari pemikiran Barat modern adalah melahirkan sikap dan paham seperti individualisme, rasionalisme, sekulerisme, dan materialisme (Meuleman, 2002: 131).

Nashr memang sangat menyesalkan banyak umat Islam dewasa ini yang justru mengambil dan mengikuti sikap dan pola pikir Barat tersebut. Baginya, kebebasan manusia yang benar adalah kesadaran akan hubungan dasar antara dirinya sendiri dan Allah SWT, seperti yang sudah seringkali dijelaskan dalam filsafat dan tasawuf Islam. Nashr meyakini ilmu pengetahuan yang benar adalah ilmu pengetahuan yang mengetahui hubungan antara yang duniawi dan yang ukhrawi. Dalam kerangka pikir ini, menurut Meuleman (2002: 132), sebagai seorang Muslim Syiah, Nashr menaruh perhatian khusus pada pemikiran Syiah dan pengungkapan nilai rohani dalam berbagi cabang seni, yang banyak dipaparkannya dalam sejumlah buku yang ditulisnya, seperti buku Ideals and Relities of Islam (1966 \& 1975), Man and Nature: The Spiritual Crisis of Modern Man (1968), Islam 
and the Plight of Modern Man (1975), dan Islamic Art and Spirituality (1987).

Konsep sentral Nashr tentang pengetahuan, sebagaimana dielaborasi dalam buku Sains dan Peradaban dalam Islam adalah unitas; yaitu paham kesatupaduan dan interelasi dari segala yang ada, sehingga dengan merenungkan kesatupaduan kosmos, seseorang dapat menuju ke arah kesatupaduan Ilahi yang dibayangkan dalam kesatuan Alam. Ide unitas dalam ilmu pengetahuan ini merupakan ide turunan dari syahadah: la ilaha illa Allah. Ide unitas bukanlah hanya sebagai sifat ilmu pengetahuan dan seni Islam, ia juga mendominasi pengungkapan ilmu pengetahuan dan seni tersebut. Dengan konsep unitas atau yang lazim disebut tauhid itu pula memungkinkan terjadinya integrasi keaneka-ragaman pengetahuan ke dalam keterpaduan. Dalam kata lain, ide unitas itu memungkinkan integrasi pengetahuan dan tindakan manusia ke dalam sebuah kesatuan yang harmonis. Sesungguhnya, menurut Nashr, ide unitas semacam ini tidak hanya khas Islam tetapi lazim dalam semua peradaban tradisional, termasuk Kristen. Namun, aplikasinya di dalam Islam mampu melahirkan sesuatu yang unik, yang tidak ditemukan dalam derajat yang sama pada peradaban dari tradisi lainnya. Menurut Nashr, kosmologi mampu untuk menjadi "alat integrasi konseptual" karena tujuannya "untuk mengadakan sebuah pengetahuan yang memperlihatkan kesalingterkaitan segala sesuatu dan mengadakan hubungan dengan tingkat-tingkat hierarki kosmik satu sama lain dan, akhirnya, dengan prinsip tertinggi. Dengan demikian, ia menjadi sebuah pengetahuan yang memungkinkan terjadinya integrasi keanekaragaman ke dalam keterpaduan. Menurutnya, adanya perbedaan pandangan dan lahirnya berbagai pemikiran tentang ilmu pengetahuan, tak lain karena adanya perbedaan tingkat fakultas yang dimiliki manusia, yang meliputi: intelek, imajinasi, rasio, dan indera (Kurniawan, 2012:12).

Nashr, menurut Meuleman, adalah penganut filsafat perenial, yaitu paham bahwa terdapat suatu pengetahuan Ilahi mendasar yang pada prinsipnya tercapai oleh setiap orang dan bersifat lintas agama dan lintas sejarah. Filsafat perenial tidak mengingkari pentingnya 
ritus dan aspek sosial dan aspek-aspek sosial setiap agama namun mengajarkan bahwa di belakangnya terdapat satu tradisi asal. Menurut Meuleman, filsafat perenial pada awalnya berkembang dalam lingkungan gnosis helenis dan dalam lingkungan Kristen, dan belakangan dikembangkan oleh Frithjof Schuon atau Muhammad Isa Nuruddin, nama setelah mualaf, terutama dalam buku Islam and the Perennial Philosophy pada 1976, selain sejumlah tokoh lain seperti Rene Guenon. Pengaruh paham filsafat perenial sangat nampak pada diri Nashr ketika ia menulis buku Knowledge and the Sacred pada 1981 (2002: 132). Filsafat perenial ditawarkan Nashr sebagai suatu perspektif alternatif untuk studi agama dan agama-agama. Sebab, pendekatan-pendekatan yang sudah mapan dalam studi agama dan agama-agama di kalangan orientalis Barat banyak yang terperangkap ke dalam historisisme. Kondisi tersebut berisiko agama atau agamaagama kehilangan makna transendentalnya, tercerabut dari akar tradisinya yang berupa asal Ilahiah yang universal, sehingga akan menjauhkan agama dari Pusatnya dan melahirkan nestapa manusia modern. Tentunya saja, hal tersebut sangat menggelisahkan sejumlah pemikir dan sarjana yang "tercerahkan", termasuk Nashr dan guru intelektualnya, F. Schuon, tokoh perenial keturunan Jerman dan kelahiran kota Bassel, Swiss, 8 Juni 1907. Dalam sebuah tulisan bertajuk "Filsafat Perenial: Perspektif Alternatif untuk Studi Agama", Nashr menjelaskan istilah "filsafat perenial" yang ia maksudkan. Istilah "filsafat perenial" dalam beberapa tulisan digunakan pula istilah "kebijaksanaan perenial" (shopia perennis), meskipun kedua istilah tersebut tidak sepenuhnya identik. Menurut Nashr, yang pertama," filsafat perenial", lebih bersifat intelektual, dan yang kedua, "kebijaksanaan perenial", lebih merupakan perealisasiannya (1992: 86).

Dalam lacakannya tentang istilah "filsafat perenial", Nashr kemudian mengelaborasi bahwa filsafat perenial memiliki cabangcabang dan ranting-ranting yang berhubungan dengan kosmologi, antropologi, seni, dan disiplin-disiplin lain, namun dalam jantungnya terletak metafisika murni. Apabila kata "metafisika" diartikan sebagai pengetahuan tentang Realitas Tertinggi, sebagai "pengetahuan mengenai yang kudus" (scientia sacra), maka kata atau konsep 
tersebut jangan dikacaukan dengan kata yang sama dalam filsafat Barat pasca abad pertengahan. Nashr menegaskan, metafisika yang dipahami dalam perspektif filsafat perenial merupakan suatu "pengetahuan Ilahiah" yang sesungguhnya, bukan suatu konstruk mental yang akan berubah dengan berubahnya gaya budaya suatu zaman, atau dengan munculnya penemuan-penemuan baru dari pengetahuan dunia material (1992: 87).

Menurut Nashr, ketika ia memaparkan perkembangan ilmu pengetahuan Islam secara historis, para ilmuwan Muslim menggunakan metode yang majemuk dalam menciptakan elemen ilmu pengetahuan Islam yang sesuai dengan makna terma "sains" saat ini. Ilmu pengetahuan Islam senantiasa berupaya menerapkan metode-metode yang beragam sesuai dengan watak subjek yang dipelajari dan cara-cara memahami subjektersebut. Para ilmuwan Muslim, dalam menumbuhkan dan mengembangkan beraneka ragam ilmu pengetahuan telah menggunakan berbagai metodologi, dari rasionalisasi dan interpretasi kitab suci hingga observasi dan eksperimentasi. Menurut Wawan Kurniawan (2012:13), tentang pemaparan Nashr mengenai ilmu pengetahuan Islam sebagai sains yang memiliki metodologinya sendiri bisa dilihat dalam berbagai karya yang membahas seputar ilmu pengetahuan Islam, misalnya, Science and Civilization in Islam; An Introduction to Islamic Cosmological Doctrine (Cambridge MA: Harvard University Press, 1964) dan (London: Thames \& Hudson, 1978); "Islamic Science, Reflection on Methodology in the Islamic Sciences" dalam Hamdard Islamicus (1980: 3-13).

Menurut Nashr, metodologi ilmu pengetahuan dalam Islam didasarkan atas sebuah epistemologi yang secara fundamental berbeda dengan epistemologi yang dominan dalam ilmu pengetahuan Barat modern. Baginya, keimanan kepada wahyu alQuran akan menyingkap semua kemungkinan yang terdapat pada akal manusia. Ketundukan kepada wahyu, pada setiap tingkat membuat akal mampu untuk mengaktualisasikan kemungkinankemungkinan ini. Pengembangan akal muslim didasarkan atas suatu kesadaran yang utuh tentang prinsip ini. Dalam perspektif ini, dalam 
memecahkan masalah-masalah filosofis dan ilmiahnya. Oleh karena itu, dapat dimengerti mengapa penyucian jiwa dipandang sebagai bagian yang terpadu dari metodologi pengetahuan. Penyucian jiwa menjadi perhatian utama, untuk proteksi dan penggunaan akal manusia dengan benar. Suasana religius dan spiritual yang tercipta dari al-Quran sekaligus menghilangkan rintangan bagi pertumbuhan akal yang wajar dan optimal, dengan cara yang benar. Intelek di sini, digunakan dalam pengertian asal, intellectus (Latin) atau nous (Yunani). Dalam bahasa al-Quran disebut 'aql yang berarti mengikat manusia ke asalnya (origin). Secara etimologis, intellect atau 'aql mempunyai makna yang sama dengan agama karena agama mengikat manusia kepada Tuhan. Pengertian itu, dalam paham modern, menurut Nashr dalam buku Knowledge and The Sacred, telah mengalami reduksi menjadi hanya reasoning semata-mata (Kurniawan, 2012:13).

\section{RELEVANSI KONSEP ILMU PENGETAHUAN NASHR DALAM DISKURSUS SAINS DAN AGAMA}

Nashr, menurut Zainal Abidin Bagir, adalah orang pertama yang menulis buku sejarah ilmu pengetahuan pada zaman Islam yang cukup komprehensif, berjudul Science and Civilization in Islam pada 1968. Sebuah hal yang lazim, sebagai rintisan awal, buku tersebut mengundang kritik dari berbagai kalangan, terutama para orientalis pengkaji sejarah ilmu pengetahuan (2002: 146). Nashr, seperti terlihat dalam banyak karyanya, memiliki pemikiran yang sangat kompleks dan multidimensional. Ia mempu membahas berbagai topik, mulai dari sains dan filsafat Islam, sufisme, perenialisme, hingga ke problem-problem yang dihadapi manusia dan peradaban modern. Menyimak pemikirannya tentang konformitas Islam dengan dunia modern, sebagian ahli memasukkan Nashr ke dalam kelompok pemikir "neomodernis" Muslim. Nashr yakin Islam dengan karakter universal dan perenialnya mampu menjawab tantangan dan krisis dunia modern (Azra, 2003: 81).

Masih dalam kerangka neomodernis Islam, Nashr adalah tokoh pengkritik yang sangat tajam dan brilian, sementara ia pun berupaya menggali dan membangkitkan warisan pemikitan Islam. Pada saat 
yang sama, Nashr mengritik dengan begitu semangat terhadap pemikir-pemikir modernis Muslim, seperti Jamaluddin al-Afgani, Muhammad Abduh, Ahmad Khan, dan Sayid Ameer Ali, yang dianggap olehnya para penyebar westernisme dan sekulerisme di dunia Muslim. Nashr menuding, mereka adalah orang-orang yang mengecilkan atau bahkan menolak unsur-unsur ajaran dan warisan pemikiran Islam yang dipandang oleh mereka sebagai tidak sesuai dengan pemikiran dan perkembangan modern. Dalam konteks sebagai seorang neomodernis, Nashr mengambil bentuk serta menghidupkan kembali Islam "tradisional". Dalam konteks ini, Nahsr memahami "tradisionalisme Islam" sebagai kepenganutan yang teguh pada "tradisi" yang suci dan mengandung kebijaksanaan perenial (abadi). Muslim tradisional, Nashr menjelaskan, adalah Muslim yang memiliki ciri-ciri sebagai berikut: pertama, menerima alQuran sepenuhnya sebagai firman Allah SWT, baik dalam isi maupun bentuk; kedua, mengakui al-kutub as-sittah (enam kitab kumpulan hadits standar); ketiga, mengandung tasawuf atau tarekat sebagai dimensi batin dan jantung pematuhan Islam; dan, keempat, selalu berangkat dari realisme sesuai dengan norma-norma Islam dalam segi politik (Azra, 2003: 81).

Selain digolongkan sebagai seorang neomodernis, Nashr juga digolongkan oleh sebagian ahli sebagai seorang pemikir "neotradisionalis". Kategori ini didasarkan pada pemikiran Nashr tentang tradisionalisme Islam dan keyakinannya mengenai kemampuan Islam dalam menjawab tantangan dunia modern. Dunia modern, menurut Nashr, ditandai oleh kecemasan terhadap bahaya perang, krisis ekologi, dan polusi udara dan air. Problem akut yang dihadapi manusia modern, dicermati Nashr, bukan muncul dari situasi keterbelakngan (underdevelopment), namun justru karena keterlalumajuan (overdevelopment). Semua problem dan krisis peradaban manusia modern ini berakar pada polusi jiwa manusia yang muncul begitu manusia Barat mengambil alih peran ketuhanan di muka bumi dengan menyingkirkan dimensi Ilahi dari kehidupannya. Manusia modern seolah mencoba "hidup dengan roti semata", "membunuh" Tuhan, dan menyatakan independensinya dari akhirat. 
Mereka melakukan desakralisasi alam untuk kemudian mengeksploitasinya secara membabi-buta dan penuh kesewenangan. Nashr mengecam, manusia modern telah memperlakukan alam seperti memperlakukan pelacur, mengambil kepuasan dari alam raya tanpa rasa tanggungjawab apapun (Azra, 2003: 82).

Di tengah krisis dan peradaban manusia modern, umat Islam terbelah menjadi dua kelompok kecenderungan: pertama, mereka yang terjebak dalam krisis dunia modern karena mengikuti pola Barat secara sembrono, dan kedua, mereka yang tetap setia kepada nilainilai tradisional Islam. Mereka masih mengamalkan ibadah dan ritual agama, berpegang pada hukum Tuhan dan menghormati ulama serta para wali. Menurut Nashr, salah satu penyebab kemunduran kehidupan internal umat Islam adalah penghancuran tasawuf dan tarekat sufi oleh gerakan-gerakan rasionalisme kelompok puritan, seperti gerakan Wahabisme di Arab Saudi dan Ahlul-hadits di India. Dalam konteks ini Nashr sangat jelas berbeda dengan sarjana Muslim lain yang justru menganggap tasawuf dan tarekat sebagai penyebab kemunduran umat Islam. Nashr menganggap positif tentang peranan sufisme dalam sejarah Islam. Bagi Nashr, sufisme ibarat jiwa yang menghidupkan tubuh. Sufisme meniupkan semangat ke dalam struktur Islam baik dalam manifestasi sosial maupun intelektual. Nashr menyimpulkan bahwa sufisme dapat menjadi jawaban dan solusi atas krisis spiritualitas manusia modern, khususnya di dunia Barat. Menurutnya, sufisme dapat mempengaruhi Barat melalui tiga upaya: pertama, mempraktekkan sufisme secara aktif; kedua, menyajikan Islam secara lebih menarik sehingga orang dapat menemukan praktek-praktek sufisme yang benar; dan, ketiga, memfungsikan sufisme untuk kebangkitan spiritualisme (Azra, 2003: $82)$.

Di dalam karya-karyanya, menurut Kurniawan, Nashr menunjukkan signifikansi religiusitas dalam upaya pengembangan ilmu pengetahuan. Nashr mengidentifikasi diri sebagai ilmuwan tradisional, di mana ia memaknai istilah tradisi sebagai menyiratkan sesuatu yang sakral. Dengan penggunaan istilah tradisi di sini, Nashr tampak menginginkan adanya kejelasan alur dan posisi pemikirannya untuk dilihat secara berbeda dari pemikiran "kontra 
tradisi", yang diidentifikasi sebagai kelompok ilmuwan modern, para pemikir Muslim modernis, dan fundamentalis. Pembedaan secara kontras ini dilakukan Nashr mengingat masing-masing kelompok itu memiliki karakteristik spesifik. Dalam wacana ilmu pengetahuan, tradisi dihadapkan pada istilah modern. Dalam konteks, istilah modern bukan dimaksudkan sebagai kontemporer atau mengikuti zaman, melainkan sesuatu yang terpisah dari yang transenden. Dengan demikian, modernisme cenderung sering dipertentangkan dengan agama, sebab mengimplikasikan semua yang semata-mata manusiawi dan semua yang tercerai dan terpisah dari sumber yang Ilahi (2012: 14).

Sebagai seorang tradisionalis, Nashr memandang perkembangan teknologi modern yang pesat dengan pesimis terutama dampak negatif yang ia soroti yaitu kerusakan lingkungan, yang terjadi mengerikan dalam beberapa dasawarsa terakhir ini. Sumber ini semua adalah teknologi yang dirancang semata-mata dengan memperhatikan nilai-nilai dunia modern, seperti efisiensi, efektivitas, dan nilai ekonomis, tanpa memperhatikan kebutuhan manusia, jasmaniah maupun ruhaniah, dan tanpa memperhatikan hubungan ruhaniah antara manusia dengan bumi dan makhluk-makhluk lainnya (Bagir, 2002: 147). Dalam buku Knowledge and The Sacred (1981) dan The Need for Sacred Science (1993), Nashr menyatakan keprihatinan terhadap kenyataan manusia modern yang terlalu sulit untuk bisa mengapresiasi hal-hal yang sakral. Dalam karya itu terungkap pula harapannya untuk membangkitkan kembali konsep scientia sacra. Dalam hal ini ia bergerak cukup jauh hingga, misalnya, mempertimbangkan kembali alkemi, yang dimaknainya bukan sebagai pendahulu ilmu kimia dalam tahapnya yang masih amat tradisional, dalam artian bersifat mistis, namun sebagai semacam jalan ruhaniah yang dipilih para ilmuwan itu. Sementara cabang ilmu pengetahuan seperti botani, misalnya, dimaknai sebagai kajian atas sifat-sifat batin tanaman, termasuk makna spiritual dan simbolisnya dalam kosmos (Bagir, 2002: 147).

Nashr menggunakan istilah "ilmu pengetahuan Islam" sebagai sistem ilmu pengetahuan yang secara amat kental disusupi oleh 
metafisika Islam. Namun semangat tingginya sebagai seorang tradisionalis menjadikan apa yang ada dalam sejarah sebagai model ideal bagi "ilmu pengetahuan Islam", yang baginya masih hidup hingga kini dan harus dilestarikan. Secara eksplisit ia menyatakan bahwa jika ia menyebut "ilmu pengetahuan Islam" dan menyatakan bahwa ilmu pengetahuan Islam masih hidup hingga kini, maka yang dimaksudkannya adalah suatu sistem ilmu pengetahuan yang berkembang pada zaman jaya peradaban Islam, dengan tokohtokohnya seperti Ibn Sina, Al-Biruni, dan Nasiruddin al-Thusi (Bagir, 2002: 146). Penting dicatat, tegas Bagir, bahwa ketika menyebut "ilmu pengetahuan Islam", Nashr memaksudkannya masih dalam kerangka scientia sacra. Nashr biasa menggunakan istilah scientia sacra (sacred science, ilmu sakral) untuk menunjukkan bahwa seharusnya aspek kearifan jauh lebih penting dalam ilmu pengetahuan daripada aspek teknologi, yang menjadi ciri utama ilmu pengetahuan modern. Dalam kerangka ini, penafsiran mistis-filososfis tentang alam sangatlah mendominasi (Bagir, 2002: 147). Demikian pula dalam bidang matematika, Nashr nampak sangat memberikan penekanan yang berlebih pada aspek mistisnya yang telah ada sejak zaman Yunani. Oleh karenanya, ditengarai Bagir, dalam penjelasan Nashr seringkali tidak nampak jelas perbedaan antara mistisisme dan ilmu pengetahuan (Bagir, 2002: 147).

Ia tampaknya secara sengaja bertahan menggunakan kata "ilmu pengetahuan" justru untuk menunjukkan betapa jauhnya ilmu pengetahuan modern kini telah menyimpang dari apa yang sesungguhnya disebut ilmu pengetahuan pada mulanya. Nashr mengkritik keras kaum modernis Islam sejak akhir abad ke-19, yang berusaha merekonstruksi pemikiran Islam agar sesuai dengan zaman modern. Menurutnya, kaum modernis itu justru telah mendistorsi tradisi intelektual Islam, semata-mata agar tampak tak "tertinggal" dibanding negara-negara Barat. Padahal, Nashr mengingatkan, di balik "kemajuan" dunia modern itu, ada kemunduran yang amat nyata, terutama dalam bidang spiritual dan kesalahpahaman dalam memahami konsep ilmu pengetahuan, sebab terjadi distorsi dalam penerjemahan kata 'ilm yang khas Islam menjadi science dalam makna modern. Bagi Nashr, istilah science adalah untuk menyebut ilmu-ilmu 
eksperimental, dan sebagai pembeda dari filsafat yang dianggap terlalu spekulatif, baru muncul pada abad ke-19. Sementara istilah Arab, al-'ilm, yang mensyaratkan kepastian (certainty), mencakup beragam jenis ilmu dan beragam metode pencapaiannya (Bagir, 2002: 146).

Dalam membicarakan sejarah ilmu pengetahuan Islam, kecenderungan mistis ini juga tampak amat kuat. Nashr memandang bahwa ada satu semangat yang selalu hadir dalam perkembangan beragam cabang ilmu pengetahuan dalam Islam, yaitu keyakinan pada tauhid. Karyanya yang terutama ditujukan untuk menunjukkan hal ini adalah An Introduction to Islamic Cosmological Doctrines. Conceptions of Nature and Methods Used for its study by the Ikhwan alSafa, al-Biruni, and Ibn Sina (1964) dan Science and Civilization in Islam (1968), yang berasal dari disertasi doktornya di Universitas Harvard. Karya tersebut sebenarnya termasuk dalam disiplin sejarah ilmu pengetahuan, namun amat kental diwarnai dengan interpretasinya yang bercorak metafisis-mistis, sehingga mendapat kritik tajam dari beberapa sejarawan ilmu pengetahuan. Perkembangan ilmu pengetahuan saat ini di dunia Islam boleh dikatakan mundur dengan ukuran apa pun, tetapi sebagai gagasan ilmu pengetahuan Islam selalu hidup, dan inilah yang tampaknya diharapkan kebangkitannya oleh Nashr (Bagir, 2002: 147). Perbedaan mendasar konstruksi ilmu di Barat dengan Islam, jika di Barat sains identik dengan teknologi dan aplikasinya, sebaliknya sains dalam pandangan Islam, disamping bermakna seperti pengertian sains dalam perspektif Barat juga bermakna pengetahuan yang berkaitan dengan spiritualitas (Ulumuddin, 2016: 9).

Bersamaan dengan makin menyebarnya filsafat perenial, pandangan Nashr kini juga dianut oleh banyak pemikir Muslim kontemporer, termasuk sangat menonjol pengaruhnya di Malaysia, yang dibawa oleh para muridnya ketika mereka menimba ilmu di Amerika, di mana Nashr lebih banyak mengabdikan diri di bidang keilmuannya. Bahkan, para intelektual muda Malaysia tersebut membentuk semacam kelompok yang menghidupkan diskusi mengenai paham filsafat perenial dalam berbagai aspeknya (Bagir, 
2002: 147). Selain itu, meluasnya pengaruh Nashr juga diperkuat oleh situasi yang saling mendukung antara posisi pemikiran Nashr terkait ilmu pengetahuan itu sendiri dengan perkembangan narasi besar yang tengah bergulir di kalangan intelektual Muslim sejak sebelumnya, terutama berkembangnya wacana baru tentang Islam dan ilmu pengetahuan berupa gagasan Islamisasi ilmu (Islamization of knowledge) atau sains Islam (Islamic science) sejak dasawarsa 1970-an hingga sekitar awal 1990-an (Bagir, 2002: 144).

Perkembangan keilmuan dalam Islam, menurut Kuswanjono, memiliki karakter yang berbeda. Kalau di Barat perkembangan ilmu diawali dengan situasi zaman yang tidak memungkinkan ilmu berkembang leluasa yaitu pada zaman Abad Pertengahan (atau dikenal sebagai zaman kegelapan ilmu), perkembangan keilmuan Islam tidak mengalami situasi itu. Sejak awal Islam mentabukan umatnya untuk berpikir yang bertentangan dengan agama (2016: 293). Sementara itu, perkembangan teknologi sebagai buah perkembangan ilmu pengetahuan amat memukau banyak orang, tidak terkecuali umat Islam. Akibatnya, sebagian ilmuwan Muslim hanya berusaha mengejar ketertinggalan umat Islam dengan mengambil alih secara menyeluruh teknologi dan ilmu pengetahuan Barat Modern. Namun, sebagian lain tidak puas dengan sikap tersebut dan menuntut Islamisasi ilmu pengetahuan atau pengembangan ilmu pengetahuan Islam. Para penggagas ilmu pengetahuan Islam atau Islamisasi ilmu pengetahuan memulai argumentasinya dari premis bahwa ilmu pengetahuan tidaklah bebas nilai. Dengan demikian, nilai-nilai apapun bisa masuk mempengaruhinya, atau bahkan berintegrasi di dalamnya, termasuk nilai-nilai sebuah agama, untuk membicarakan perihal ilmu pengetahuan. Menurut Bagir, adalah hal yang wajar ketika kemudian muncul kritik, bahkan serangan, terhadap gagasan ini yang biasanya berupa upaya mempertahankan premis penting itu, yang pada umumnya datang dari praktisi ilmu pengetahuan Muslim, seperti Professor Abdussalam, peraih penghargaan prestisius, Nobel Awards bidang fisika (Bagir, 2002: 145).

\section{SIMPULAN}


Berdasarkan pemaparan di atas, maka dapat disimpulkan bahwa: Pertama, konsep tradisionalisme Islam sangat mempengaruhi pandangan Nashr mengenai pengetahuan. Konsep tradisionalisme Islam yang diajukan Nashr adalah sebuah gerakan atau upaya mengajak kembali ke 'akar tradisi', sebagai "Kebenaran dan Sumber asal segala sesuatu", dengan mencoba mengaitkan antara sekuleritas Barat dengan dimensi ke-Ilahiah-an yang bersumber pada wahyu agama. Dalam konteks ini, Nashr menawarkan agar nilai kesucian dari Islam dapat menjiwai pengetahuan yang berasal dari di Barat lebih berkembang daripada dunia Islam kontemporer, sehingga tidak perlu disingkirkan sama sekali.Tawaran Nashr ini berdasarkan keyakinan bahwa ilmu pengetahuan yang benar adalah ilmu pengetahuan yang mengetahui hubungan antara yang duniawi dan yang ukhrawi. Ketika pemikiran modern Barat memandang bahwa objek ilmu pengetahuan hanyalah realitas empirik, Nashr justru menjangkau keseluruhan realitas dari yang eksternal hingga yang paling internal. Berbagai realitas itu dipadukan dalam kalimat, la ilaha ilia Allah, sebagai konsep dasar Islam, tauhid; yang bagi Nashr dianggap sebagai formulasi metafisikal yang paling mendalam. Dengan demikian, konsep Nashr tentang ilmu pengetahuan adalah bertumpu pada prinsip unitas atau tauhid; yaitu paham kesatupaduan dan interelasi dari segala yang ada, sehingga memungkinkan terjadinya integrasi pengetahuan dan tindakan manusia ke dalam sebuah kesatuan yang harmonis.

Kedua, Syed Hussein Nashr merupakan orang pertama yang menulis buku sejarah ilmu pengetahuan pada zaman Islam yang cukup komprehensif. Dalam banyak karya, Nashr juga mengemukakan pemikiran yang sangat kompleks dan multidimensional, dengan membahas berbagai topik, mulai dari sains dan filsafat Islam, sufisme, perenialisme, hingga ke problem-problem yang dihadapi manusia dan peradaban modern. Secara umum, Nashr meyakini Islam dengan karakter universal dan perenialnya mampu menjawab tantangan dan krisis dunia modern. Semua problem dan krisis peradaban manusia modern tersebut berakar pada polusi jiwa manusia yang muncul begitu manusia Barat mengambil alih peran 
ketuhanan di muka bumi dengan menyingkirkan dimensi Ilahi dari kehidupannya. Nashr prihatin terhadap kenyataan manusia modern yang terlalu sulit untuk bisa mengapresiasi hal-hal yang sakral.Nashr menekankan signifikansi religiusitas dalam upaya pengembangan ilmu pengetahuan. Pengertian ilmu pengetahuan pada Nashr berbeda amat jauh dengan ilmu pengetahuan sebagaimana yang lazim dipahami kini. Oleh sebab itu, Nashr menggunakan istilah scientia sacra (ilmu sakral) untuk menunjukkan bahwa seharusnya aspek kearifan jauh lebih penting dalam ilmu pengetahuan daripada aspek teknologi, yang menjadi ciri utama ilmu pengetahuan modern. Ia tampaknya secara sengaja bertahan menggunakan kata "ilmu pengetahuan" justru untuk menunjukkan betapa jauhnya ilmu pengetahuan modern kini telah menyimpang dari apa yang sesungguhnya disebut ilmu pengetahuan pada asal mulanya. Pandangan Nashr kini juga dianut oleh banyak pemikir Muslim kontemporer. Meluasnya pengaruh Nashr juga diperkuat oleh situasi yang saling mendukung antara posisi pemikiran Nashr terkait ilmu pengetahuan itu sendiri dengan perkembangan narasi besar yang tengah bergulir di kalangan intelektual Muslim, terutama berkembangnya wacana baru tentang Islam dan ilmu pengetahuan berupa gagasan Islamisasi ilmu atau sains Islam.

\section{DAFTAR PUSTAKA}

Abidin, Zaenal. 2008, Pemikiran Razi Al-Faruqi (1921-1986) Tentang Islamisasi Sains Dan Pengaruhnya Terhadap Pengembangan DasarDasar Filosofis Pendidikan Islam, Jakarta: Program Doktor Uin Syarif Hidayatullah.

Azra, Azyumardi, dkk. (eds.), 2003. "Nasr, Sayid Husein" dalam Suplemen Ensiklopedi Islam, Jakarta: PT. Ichtiar Baru Van Hoeve, hal. 80-82.

Bagir, Zainal Abidin. 2002, "Pergolakan Pemikiran Di Bidang Ilmu Pengetahuan", dalam Taufik Abdullah,dkk. (ed.), Ensiklopedi Tematis Dunia Islam Dinamika Masa Kini, Jakarta: PT. Ichtiar Baru Van Hoeve, hal. 137-159. 
2006, “Agama dan sains-Agama: Perbandingan Beberapa Tipologi Mutakhir ", dalam Zainal Abidin Bagir, Lik Wilardjo, Arqom Kuswanjono, dan Muhammad Yusuf (eds.), Ilmu, Etika, Dan Agama, Menyingkap Tabir Alam dan Manusia, Yogyakarta: CRCS UGM, hal. 3-18.

2008, "Sains dan Islam dan Upaya Perluasan Panggung "Sains dan Agama", dalam J. Sudarminta dan S.P. Lili Tjahjadi (eds.), Dunia, Manusia E Tuhan, Dua Belas Esai Pencerahan, Festschrift untuk merayakan 80 Tahun Prof. Dr. Louis Leahy, S.J., Yogyakarta: Penerbit Kanisius, hal. 49-68.

Eliade, Mircea. 2000, "Kronologi Studi Agama sebagai Disiplin Ilmu" di dalam Ahmad Norma Permata (ed.), Metodologi Studi Agama, Yogyakarta: Pustaka Pelajar, hal. 61-72.

Hanaf, Afdhol Abdul, dkk, 2011. "Tradisionalisme Islam Sayyed Hossein Nasr", http://afdholhanaf.blogspot.co.id/2011/11/vbehaviorurldefaultomlo.html, diakses 1 Februari 2017 pkl. 20.15 WIB.

Hidayatullah, Syarif, 2006, "Relasi Filsafat Dan Agama (Perspektif Islam)", Jurnal Filsafat Vol. 40, Nomor 2, Agustus 2006, https://jurnal.ugm.ac.id/wisdom/article/view/31271, hal. 128-148.

2011, Studi Agama: Suatu Pengantar, Yogyakarta: Tiara Wacana Yogya.

2017, Relasi Agama dan Sains Dalam Pandangan Mehdi Golshani, Jurnal Filsafat Vol. 27, No 1 (2017), https://jurnal.ugm.ac.id/wisdom/article/view/21972, hal. 65-90, DOI: http://dx.doi.org/10.22146/jf.21972

Kuswanjono, Arqom. 2010, Integrasi Ilmu dan Agama Perspektif Filsafat Mulla Sadra, Yogyakarta: Badan Penerbit Filsafat UGM.

2016, Hakikat Ilmu Dalam Pemikiran Islam, Jurnal Filsafat Vol. 26, No 2 (2016), https://jurnal.ugm.ac.id/wisdom/article/view/12787 hal. 291-321, DOI: https://doi.org/10.22146/jf.12787

Kurniawan, Aris. 2010,"Pengetahuan Dan Kesucian Menurut Sayyid Hussein Nasr", https://ariskfiles.blogspot.co.id/2010/07/pengetahuandan-kesucian-menurut-sayyid.html, diakses 25 Januri 2017 pkl. 21.00 WIB. 
Kurniawan, Wawan. 2012, "Pemikiran Seyyed Hossein Nasr Tentang Epistemologi",

https://aweygaul.wordpress.com/2012/08/09/pemikiran-seyyedhossein-nasr-tentang-epistemologi/, diakses 25 Januari 2017 pkl. 21.00 WIB.

Meuleman, John Hendrik. 2002, "Pergolakan Pemikiarn Keagamaan” dalam Taufik Abdullah, dkk., Ensiklopedia Dunia Islam Dinamika Masa Kini, Jakarta: PT. Ichtiar Baru Van Hoeve, hal.119-135.

Nashr, Seyyed Hossein. 1975, Islam and the Plight of Modern Man, Chicago: ABC Internatioan Group, Inc. 1983, Islam antara Cita dan Fakta, terj. Abdurrahaman Wahid dan Hasyim Wahid, Jakarta: LEPPENAS, PT. Panca Gemilang Indah

1989,Knowledge and The Sacred, New York : State University of New York Press.

1992, "Filsafat Perenial: Perspektif Alternatif untuk Studi Agama", terj. Saeful Muzani, dalam Ulumul Qur'an, Vol. III, No. 3, Thn. 1992: 86-95.

1996,Religion and The Order of Nature, New York: Oxford University Press

Syamsuddin, Ach. Maimun. 2012, Integrasi Multidimensi Agama E Sains, Yogyakarta: IRCiSoD

Solichun, Muhammad. 2011, "Epistemologi Ilmu Seyyed Hossein Nasr", http://mikasahabat.blogspot.co.id/2012/03/epistimologi-ilmuseyyed-hossein-nasr.html, diakses 1Februari 2017 pkl. 20.15 WIB.

Ulumuddin, 2016. "Pemikiran Seyyed Hossein Nasr", http://ulumuddinwanderer.blogspot.co.id/2016/01/pemikiran-seyyedhossein-nasr.html, 2 Januari 2016,diakses 25 Januari 2017 pkl. 20.30 WIB.

Wijaya, Cuk Ananta, 2006, "Ilmu Dan Agama Dalam Perspektif Filsafat Ilmu", Jurnal Filsafat Vol. 40, Nomor 2, Agustus 2006, https://jurnal.ugm.ac.id/wisdom/article/view/23207, hal. 174-188.

Yakub, Ikhsan. 2013, "Manusia Modern Dalam Pandangan Sayyed Hossein Nasr", http://ikhsanyaqub.blogspot.co.id/2013/07/manusia- 
modern-dalam-pandangan-sayyed.html, 30 Juli 2013, diakses 1 Februari 2017 pkl. 20.20 WIB.

Zainal, Nurdin. 2017. "Biografi Dan Pemikiran SYD Hosen Nasr", http://www.academia.edu/8165068/BIOGRAFI_DAN_PEMIKIRAN_ SYD_HOSEN_NASR, diakses 25 Januari 2017 pkl, 21.00 WIB. 